\title{
Evaluation of Cicer Milkvetch and Alfalfa Cultivars for Nutritive Value, Anti-Quality Factors and Animal Preference
}

\author{
Herbert Lardner ${ }^{1,2}$, Leah Pearce ${ }^{1} \&$ Daalkhaijav Damiran ${ }^{1,2}$ \\ ${ }^{1}$ Department of Animal and Poultry Science, University of Saskatchewan, Saskatoon, Saskatchewan, S7N 5A8, \\ Canada \\ ${ }^{2}$ Western Beef Development Centre, Lanigan, Saskatchewan, S0K 2M0, Canada \\ Correspondence: Herbert Lardner, Department of Animal and Poultry Science, University of Saskatchewan, \\ Saskatoon, Saskatchewan, Canada. E-mail: bart.lardner@usask.ca
}

Received: September 14, 2018 Accepted: September 30, 2018 Online Published: October 16, 2018

doi:10.5539/sar.v8n1p1 URL: https://doi.org/10.5539/sar.v8n1p1

\begin{abstract}
Cicer milkvetch (CMV; Astragalus cicer L.) is an alternative non-bloat legume to managing alfalfa. A 2-yr study was conducted to compare three CMV cultivars (Oxley II, Oxley, and Veldt) to AC Grazeland alfalfa (ALF; check forage) for nutritive value and animal preference. Each yr, replicate samples $(n=4)$ of each forage type were harvested late summer and analyzed for nutrient profile. Oxley II had lower $(p<0.05)$ fiber content than AC Grazeland, while Oxley and Veldt were similar $(p=0.48)$ to AC Grazeland for neutral detergent fibre (NDF), acid detergent fibre (ADF) and starch. In contrast, Oxley II had higher $(p<0.05)$ net energy for gain $\left(\mathrm{NE}_{\mathrm{g}}\right)$ than AC Grazeland, and Oxley and Veldt were similar $(p>0.05)$ to AC Grazeland for NE . All three CMV varieties had similar levels of total digestible nutrients (TDN) $(63.6 \pm 0.6 \% ; p>0.05)$, but had higher $(p=0.01)$ energy content than AC Grazeland alfalfa $(54.9 \pm 1.4 \% \mathrm{TDN})$. Selenium (Se) concentrations were similar $(p>0.05)$ among CVM cultivars and less than $1 \mathrm{mg} / \mathrm{kg}$ DM, and no swainsonine or nitrotoxins were detected in the CMV cultivars. The Oxley II CMV tended $(p=0.06)$ to have a higher (139) relative feed value (RFV) compared to AC Grazeland (94), while Oxley and Veldt had moderate RFV values (128). Dry matter intake of Oxley II, Veldt, and Oxley CMV was 4, 18, and $28 \%$ greater than AC Grazeland, respectively. Based on the relative preference index (ratio of forage DMI to AC Grazeland alfalfa DMI), forage types are ranked as follows: AC Grazeland (1.0) < Veldt (1.2) < Oxley (1.4) < Oxley II (1.7). Study results suggest that CMV cultivars harvested late summer, maintained higher forage quality with greater preference compared to alfalfa.
\end{abstract}

Keywords: alfalfa, Astragalus cicer L., cicer milkvetch, palatability, preference

\section{Introduction}

In North America, cicer milkvetch (Astragalus cicer L.) (CMV) is an alternative legume to alfalfa (Acharya et al., 2006). Cicer milkvetch is a long-lived, winter-hardy, acid- and drought-tolerant crop. It maintains high quality throughout the growing season and, in contrast with most other forage legumes does not cause bloat in ruminants (Acharya et al., 2006) and is used for pasture grazing in the moister regions of Saskatchewan. However, adoption of CMV as a grazing species has been limited due to poor germination, poor seedling vigour, and slow stand establishment (Smoliak et al., 1972; Acharya et al., 2006). Two new cultivars have been released, Oxley II (Acharya, 2001) and Veldt (Acharya, 2009) both with improved seedling vigour. Oxley II (Acharya, 2001) and "Veldt" (Acharya, 2009) are newer cultivars of CMV that have been developed and released in recent years with improved seedling vigour and greater forage yield compared to Oxley. In North America, CMV is an alternative legume to alfalfa (Acharya et al., 2006), therefore in the current study AC Grazeland alfalfa (Coulman et al., 2000) was used as a check (control) forage. There is the expectation that the number of hectares of alfalfa grazed in western Canada will increase, and because of this, producers who want to reduce the risk of bloat occurring in their grazing animals will be interested in CMV cultivars (Coulman et al., 2000). In a study at Melfort, Saskatchewan, CMV exhibited greater leaf retention and higher digestibility in the fall compared to alfalfa (Loeppky et al., 1996). This earlier study evaluated an older CMV cultivar, Oxley while these results have not been confirmed evaluating newer CMV cultivars. Limited information is available on comparing forage quality and grazing animal preference of CMV varieties and alfalfa during late summer or early fall (Jefferson et al., 2015). Producers like the low management input characteristics of CMV pastures combined with the higher animal 
gains compared to grass only pastures (Acharya, 2006). However, there is concern with respect to feeding or grazing CMV because several close relatives of this species are known to accumulate secondary compounds that are toxic to grazing livestock (Damiran, 2005). For example, the native milkvetch, Astragalus bisulcatus, is a known toxic plant that occurs on Saskatchewan rangelands. On high selenium soils, this milkvetch can accumulate toxic levels of this mineral. Other Astragalus species can accumulate toxic levels of swainsonine and indolizidine alkaloid that causes neurological disorders in livestock including reduced appetite and growth, cessation of reproduction and abortion (Cheeke, 1998; Damiran, 2005). Therefore, the objectives of this study were to compare three cicer milkvetch cultivars (Veldt, Oxley, and Oxley II) and AC Grazeland alfalfa (check forage) in terms of detailed chemical composition including energy, protein and carbohydrate sub-fractions, anti-quality profile, and animal preference of forages grown in the Thin Black/Dark Brown soil zone of Saskatchewan.

\section{Materials and Methods}

\subsection{Study Site and Forage Management}

The 2-yr study was conducted at Western Beef Development Centre's (WBDC), Termuende Research Ranch near Lanigan, Saskatchewan, $\left(51^{\circ} 51 \mathrm{~N}, 105^{\circ} 02 \mathrm{~W}\right)$. Forages were grown and harvested on a research site, where soils classification is Chernozemic Black Oxbow (Saskatchewan Soil Survey, 1992). Three CMV cultivars, Oxley II, Oxley, and Veldt were compared to AC Grazeland alfalfa for nutritive value and animal preference. Oxley cicer milkvetch was developed from selections made from a population introduced from the former USSR to the Dominion Range Experimental Station, Manyberries, AB (Johnston et al., 1971) and is widely adapted to the Dark Brown and Black soil zones of western Canada (Acharya et al., 2006). The current study evaluated forages in previously established research plots at WBDC Termuende Research Ranch, Lanigan, Saskatchewan. Details of establishment, agronomy and biomass management are described in Jefferson et al. (2015). Briefly, there were 9 plots of each cultivar utilized in the current study, with the potential yield averaging 85, 96, and 129\% (Jefferson et al., 2015) of AC Grazeland alfalfa for Oxley, Oxley II, and Veldt cultivars, respectively.

\subsection{Forage Collection and Lab Analyses}

Each year, samples of each forage type were harvested from plots at start and end of preference study (data collection period; $\mathrm{n}=2$ ). Forage samples were placed in paper bags, dried in a forced air oven at $55^{\circ} \mathrm{C}$ for $72 \mathrm{~h}$ for DM, and ground to pass through a 1-mm screen using a Wiley mill (Model 4, Arthur H. Tomas Co., Philadelphia, PA). All nutritive analysis of samples was conducted by A\&L Canada Laboratories Inc. (London, ON). Samples were analyzed for dry matter (DM; AOAC method \# 930.15), ash (AOAC method \# 942.05), crude fat (AOAC method \# 920.02), and crude protein (CP; AOAC method \# 984.13) content according to the procedures of AOAC (2000). Crude protein was determined using a Leco FP-2000 nitrogen analyzer (Leco Corporation, St. Joseph, MI), soluble protein by the borate-phosphate procedure (Krishnamoorthy et al., 1982), acid detergent insoluble crude protein (ADICP; method 990.03; AOAC, 2000), neutral detergent insoluble crude protein (NDICP; method 990.03; AOAC, 2000) and rumen degradable protein (RDP) by the procedure outlined by Krishnamoorthy et al. (1983). Acid detergent fiber (ADF), neutral detergent fiber with heat stable $\alpha$-amylase (NDF), and acid detergent lignin (ADL) were analyzed according to the procedures of Van Soest et al. (1991) using an ANKOM Fiber Analyzer (ANKOM Technology Corporation., Fairport, NY). Starch analyzed as described by Hall (2009), ash (method 942.05; AOAC, 2000), fat using a tecator extraction unit (method 2003.05; AOAC, 2000) and minerals by method 985.01 (AOAC, 2000). Total digestible nutrients (TDN) and digestible energy (DE) levels were determined according to Weiss et al. (1992). The net energy for maintenance $\left(\mathrm{NE}_{\mathrm{m}}\right)$, and net energy for gain $\left(\mathrm{NE}_{\mathrm{g}}\right.$ ) were calculated according to NRC Dairy (2001) and NRC Beef (2000), respectively. Non-fiber carbohydrate (NFC) was calculated as NFC, $\%=100-(\mathrm{CP}, \%+$ Fat, $\%+$ Ash, $\%+$ NDF, $\%+$ NDICP, \%; Linn, 2003) where NDICP is neutral detergent insoluble crude protein. Nonstructural carbohydrate content (NSC) was calculated as sum of sugars, starch, organic acids and fructans (NRC, 2001). Relative feed value was calculated as $\mathrm{RFV}=(\mathrm{DDM} \times \mathrm{DMI}) / 1.29$ (Undersander \& Moore, 2002) where DDM = digestible $\mathrm{DM}$ and calculated as $88.9-(0.779 \times \% \mathrm{ADF})$ and $\mathrm{DMI}=$ dry matter intake calculated as $120 / \% \mathrm{NDF}$. All analyses are reported on a DM basis. Anti-quality profile (swainsonine, nitrotoxins, and selenium) analysis of forages was conducted using gas chromatography coupled with mass spectrometry by the Poisonous Plant Research Lab located at USDA-ARS (Logan, UT, USA).

\subsection{Forage Preference Study}

For the study, a $50 \times 120 \mathrm{~m}$ drylot pen surrounded by wooden slatted fences with $20 \%$ porosity was uses, and contained an open-faced shed at one end with water supplied in a heated water bowl. Along one side of the pen, 4 GrowSafe Intake (GrowSafe Systems Ltd., Airdrie, Alberta, Canada) feeding nodes were installed and individual forage intake was measured. Details of feeding systems and facilities at WBDC are further described 
in Damiran et al. (2018). Four Angus cows (body weight $=645 \pm 21 \mathrm{~kg}$ ) were used for forage preference study, and each cow was identified with a half-duplex radio frequency transponder button (Allflex USA Inc., Dallas/Ft. Worth Airport, TX) in the right ear. The transponder button was located 5 to $6 \mathrm{~cm}$ from the base of the ear, in the middle, with the transponder button on the inside part of the ear. All experimental procedures were approved by University of Saskatchewan Animal Care Comittee (Protocol No. 20090107) and all animals were cared for in accordance with the Canadian Council of Animal Care guidelines (CCAC, 2009). During the entire study period all cows had ad libitum access to the nodes containing the different forage types.

\subsection{Feeding Management}

Fresh forage of the three CMV cultivars, Oxley, Oxley II and Veldt, and AC Grazeland alfalfa were harvested from research plots daily, using a Jari Mower, with sufficient fresh CMV and AC Grazeland harvested to fill each GrowSafe node each morning for both adaptation and data collection periods. Cows were then monitored for forage preference bout behavior visually and from the GrowSafe computer to ensure that all cows were consuming forage at all nodes by the end of the adaptation period.

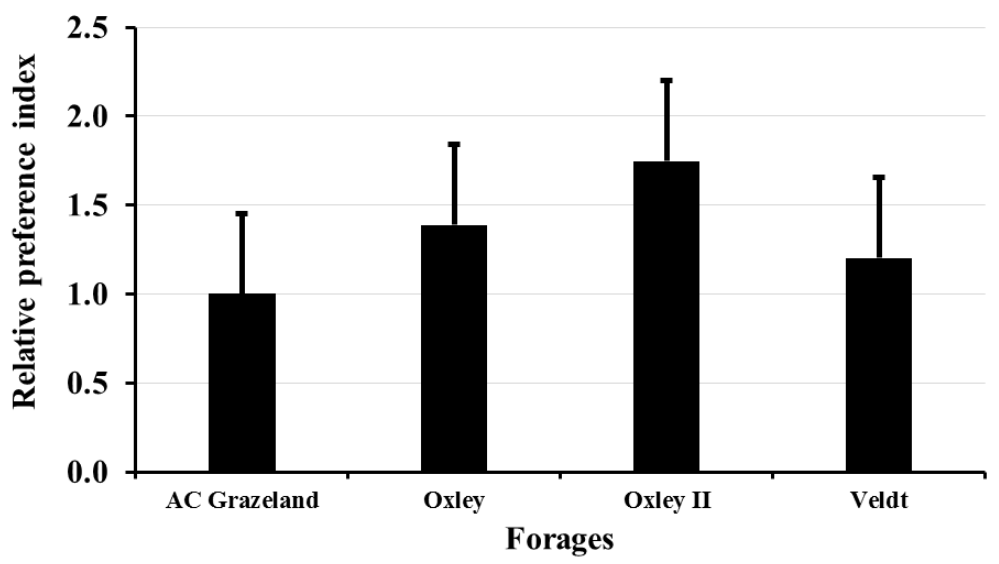

Figure 1. Mean relative preference index for four forage types

Note. Relative preference index: a ratio of plant DMI rate to the alfalfa (check cultivar) DMI rate

All four forages where at full flower stage at time of harvest. The fresh weight of each forage type was recorded prior to each forage being placed into 1 of 4 GrowSafe nodes. The study period was conducted late summer each year as other studies have reported that CMV produces high-quality forage late in the season (Johnston, Smoliak, Hironaka, \& Hanna, 1971; Smoliak \& Johnston, 1976; Acharya et al., 2006); therefore, CMV may be useful as a late-season species in pasture mixtures with cool-season grasses and other legumes (Townsend, Kenno, \& Brick, 1990). Cows were acclimated to the individual GrowSafe feed nodes (bunks) for $7 \mathrm{~d}$ before the initiation of the study. Each study period consisted of a $7 \mathrm{~d}$ acclimation followed by $9 \mathrm{~d}$ preference data collection. During the acclimation period, a control forage (mixed grass-legume hay, $11.6 \% \mathrm{CP} ; 54.7 \% \mathrm{TDN}$; DM basis) was fed in equal portions in all four feeding compartments. The 2-yr preference study was conducted from August 19 to September 3, 2016 (yr 1) and August 17 to September 1, 2017 (yr 2). On each day, each of the 4 nodes was randomly assigned to 1 of 4 forage types, Oxley, Oxley II, Veldt or AC Grazeland. Harvested forages from plots of each cultivar were collected and placed in assigned node in the morning. Prior to adding fresh forage, at 0800 $\mathrm{h}$ the previous day orts were removed and weighed before fresh cut forage was provided in the GrowSafe nodes. To ensure animals always had access to the experimental forages during the study period, a minimum of $10.0 \mathrm{~kg}$ of forage (DM basis) was maintained by adding forage as needed after each hour of monitoring. Additional forage was only added to the node needing forage to achieve the minimum of $10.0 \mathrm{~kg}$. To minimize the potential for alterations in DMI due to the addition of feed, all tubs were removed to weigh the remaining feed each hour and add the additional feed. Based on the feeding observations, adding feed had minimal influence on DMI. Animal preference was determined based on DM disappearance for the first $6 \mathrm{~h}$ immediately post-feeding.

Palatability is the interrelationship between a food's flavor (odor, taste, and texture) and the post-ingestive effects of nutrients and toxins; both are influenced by a plant's chemical characteristics and an animal's nutritional state and past experiences with the food (Provenza, 1995; Damiran, 2005). The most common measure of palatability is the relative preference index (RPI). In the current study, forage intake rate and related corresponding feeding behavior data was measured with the GrowSafe automatic feeding system (GrowSafe Systems Ltd., Airdrie, 
Alberta), which monitors individual animal feed intake and feeding behaviors, as described by Durunna et al. (2011). Subsequent feeding and behavioral data were recorded as the animal is feeding from the nodes. Data generated from the feeding units are stored in the data logging reader panel and are transferred wirelessly to the personal computer located about $100 \mathrm{~m}$ away. The feeding behaviors measured included feeding event frequency (EF; events/h), feeding event duration (FD; $\mathrm{min} / \mathrm{h}$ ), and feeding event head-down time (FHD; $\mathrm{min} / \mathrm{h}$ ) during data collection. Feed intake rate (FI, as fed) was the average feed intake for valid test $\mathrm{h}$ for each test day. DMI rate, $(\mathrm{g} / \mathrm{h})=\sum \mathrm{FI}_{i}\left(\mathrm{DM}_{i} / 100\right)$; where: $\mathrm{FI}_{i}$ is the amount of forage (as is) of each cow during foraging study $(\mathrm{g} / \mathrm{h})$ for each node, and $\mathrm{DM}_{i}=\mathrm{DM}$ composition of each forage species $i(\%)$. Data were generated from the feeding units for 24 $\mathrm{h}$ continuously. However, we considered the first $6 \mathrm{~h}$ data as valid of forage preference and subjected to analysis. Reason is during that time all forages were available to animals. Forage ranking (Rank) category was achieved by giving the ranking ' 1 ' to the highest DMI rate value for each forage within each day, ' 2 ' to the second highest value, ' 3 ' to the third highest value, ' 4 ' to the fourth highest value and ' 5 ' to the lowest DMI rate. Forage relative preference index (RPI) was developed to account for differences in preference between forages. Each forage RFI was calculated using the following equation:

\section{RPI = each CMV forage DMI rate / AC Grazeland DMI rate}

The RPI shows which forage was preferred more than or less than compared to the check (control) forage (AC Grazeland alfalfa). To interpret the results of the RPI, a RPI approximately equal to 1 means CMV forages are preferred similar to AC Grazeland alfalfa. A RPI $<1$ means CMV forages are preferred less than AC Grazeland alfalfa, and an RPI $>1$ means CMV forages are preferred more than AC Grazeland alfalfa. In each case, the RPI assumes that each forage has an equal opportunity to be selected by the animals. Thus, lower rank or RPI value reflects the less preferred forage, with a high rank or RPI value, reflecting a higher preference for that forage type.

\subsection{Statistical Analysis}

Forage nutrient profile, feeding behavior (FD, FHD, FF, DMI rate) for each forage, rank and relative preference index data were analyzed using the MIXED procedure of SAS 9.2 (SAS, 2003). The model used for the analysis was: $Y_{i j}=\mu+T_{i}+e_{i j}$; where $Y_{i j}$ was an observation of the dependent variable $i j ; \mu$ was the population mean for the variable; $\mathrm{T}_{\mathrm{i}}$ was the fixed effect of the forage type (Oxley, Oxley II, and Veldt, and AC Grazeland alfalfa); and $\mathrm{e}_{\mathrm{ij}}$ was the random error associated with the observation $\mathrm{ij}$. When a significant difference was detected $(p<$ 0.05), means were separated using the Tukey-Kramer post-test. For preference, behavior and DMI study, each node in each study $\mathrm{d}$ was considered an experimental unit making for a total of 72 experimental units (4 nodes/cultivars $\times 9$ data collection $\mathrm{d} \times 2 \mathrm{yr}$ ) over the 2 -yr study. Year was included as a random (block) variable in all analyses.

\section{Results and Discussions}

\subsection{Forage Nutritive Value}

There is demand in the Parkland region of western Canada for persistent perennial legumes that can be grazed in the late-summer and fall (Loeppky et al., 1996). All four forages were at full flower stage as the current study was conducted in late-summer. Chemical composition, protein and carbohydrate fraction profiles, and predicted energy values for forages are shown in Table 1 . There were no differences $(p>0.05)$ in DM $(32.5 \pm 3.11 \%$; Mean $\pm \mathrm{SE})$, ash $(7.9 \pm 0.21 \%)$, crude fat $(2.3 \pm 0.10 \%)$, acid detergent lignin $(7.6 \pm 0.3 \%)$, nonstructural carbohydrate $(26.3 \pm 1.8 \%)$, CP $(15.4 \pm 0.7 \%)$, soluble protein $(35.7 \pm 0.1 \%$ of CP), neutral detergent insoluble CP $(4.8 \pm 0.2 \%)$, acid detergent insoluble $\mathrm{CP}(1.8 \pm 0.1 \%)$, net energy for gain $(0.73 \pm 0.04 \mathrm{Mcal} / \mathrm{kg})$, calcium $(1.4 \pm 0.13 \%)$, chloride $(0.3 \pm 0.05 \%)$, phosphorus $(0.19 \pm 0.01 \%)$, sulphur $(0.34 \pm 0.10 \%)$, magnesium $(0.46 \pm 0.08 \%)$, copper $(4.4 \pm 0.36 \mathrm{~g} / \mathrm{kg})$, zinc $(10.1 \pm 0.62 \mathrm{~g} / \mathrm{kg})$, or iron $(83.3 \pm 5.3 \mathrm{~g} / \mathrm{kg})$, between the three CMV cultivars and AC Grazeland alfalfa. 
Table 1. Chemical composition of cicer milkvetch and alfalfa grown at WBDC Termuende Research Ranch, Lanigan, Saskatchewan, CANADA (2016 and 2017)

\begin{tabular}{|c|c|c|c|c|c|}
\hline & Alfalfa & & icer milkvetch & & \\
\hline Item & AC Grazeland & Oxley & Oxley II & Veldt & $p$-value \\
\hline Dry matter $(\mathrm{DM})$ & $32.4 \pm 4.3$ & $33.4 \pm 7.2$ & $31.8 \pm 7.6$ & $32.3 \pm 9.2$ & 0.99 \\
\hline \multicolumn{6}{|l|}{ Chemical profile $(\%, \mathrm{DM})$} \\
\hline Ash & $7.4 \pm 0.50$ & $7.8 \pm 0.51$ & $8.0 \pm 0.22$ & $7.9 \pm 0.17$ & 0.75 \\
\hline Crude fat & $2.4 \pm 0.09$ & $2.1 \pm 0.08$ & $2.2 \pm 0.08$ & $2.5 \pm 0.23$ & 0.22 \\
\hline \multicolumn{6}{|c|}{ Structural carbohydrate profile $(\%, \mathrm{DM})$} \\
\hline Acid detergent fibre & $43.2 \pm 1.41^{\mathrm{a}}$ & $37.5 \pm 3.50^{\mathrm{ab}}$ & $34.0 \pm 0.53^{\mathrm{b}}$ & $36.8 \pm 0.46^{\mathrm{ab}}$ & 0.05 \\
\hline Neutral detergent fibre & $54.2 \pm 1.44^{\mathrm{a}}$ & $46.1 \pm 3.84^{\mathrm{ab}}$ & $41.8 \pm 0.99^{b}$ & $44.6 \pm 1.31^{\mathrm{ab}}$ & 0.02 \\
\hline Acid detergent lignin & $8.3 \pm 0.50$ & $7.7 \pm 0.72$ & $7.2 \pm 0.10$ & $7.7 \pm 0.14$ & 0.42 \\
\hline \multicolumn{6}{|c|}{ Nonstructural carbohydrate profile (\%, DM) } \\
\hline Total & $21.7 \pm 1.94$ & $26.0 \pm 2.78$ & $30.3 \pm 0.11$ & $27.0 \pm 0.60$ & 0.10 \\
\hline Starch & $3.8 \pm 0.17^{\mathrm{a}}$ & $2.2 \pm 0.26^{\mathrm{ab}}$ & $1.9 \pm 0.61^{\mathrm{b}}$ & $2.9 \pm 0.33^{\mathrm{ab}}$ & 0.03 \\
\hline \multicolumn{6}{|l|}{ Crude protein profile $(\%, \mathrm{CP})$} \\
\hline Crude protein $(\%, \mathrm{DM})$ & $14.1 \pm 0.91$ & $16.1 \pm 1.34$ & $16.9 \pm 1.81$ & $16.3 \pm 0.84$ & 0.49 \\
\hline Soluble protein & $35.7 \pm 0.06$ & $35.7 \pm 0.09$ & $35.7 \pm 0.14$ & $35.8 \pm 0.07$ & 0.83 \\
\hline Neutral detergent insoluble CP & $4.4 \pm 0.14$ & $4.9 \pm 0.33$ & $4.9 \pm 0.17$ & $4.8 \pm 0.18$ & 0.33 \\
\hline Acid detergent insoluble $\mathrm{CP}$ & $1.6 \pm 0.23$ & $1.8 \pm 0.06$ & $1.9 \pm 0.03$ & $1.9 \pm 0.10$ & 0.48 \\
\hline Rumen degradable $\mathrm{CP}$ & $67.6 \pm 1.09$ & $68.8 \pm 1.30$ & $68.3 \pm 0.64$ & $67.3 \pm 1.52$ & 0.78 \\
\hline Total digestible nutrients (\%) & $54.9 \pm 1.38^{\mathrm{b}}$ & $62.6 \pm 1.26^{\mathrm{a}}$ & $65.1 \pm 1.18^{\mathrm{a}}$ & $63.8 \pm 0.14^{\mathrm{a}}$ & $<0.01$ \\
\hline \multicolumn{6}{|l|}{ Energy values (Mcal/kg DM) } \\
\hline Net energy for gain & $0.59 \pm 0.03^{b}$ & $0.72 \pm 0.08^{\mathrm{ab}}$ & $0.81 \pm 0.01^{\mathrm{a}}$ & $0.74 \pm 0.01^{\mathrm{ab}}$ & 0.05 \\
\hline Net energy maintenance & $1.21 \pm 0.03$ & $1.34 \pm 0.13$ & $1.43 \pm 0.06$ & $1.36 \pm 0.06$ & 0.30 \\
\hline Relative feed value & $93 \pm 9$ & $127 \pm 14$ & $139 \pm 1$ & $128 \pm 7$ & 0.06 \\
\hline \multicolumn{6}{|l|}{ Macro elements (\%, DM) } \\
\hline Calcium & $1.41 \pm 0.30$ & $1.27 \pm 0.16$ & $1.14 \pm 0.13$ & $1.21 \pm 0.20$ & 0.82 \\
\hline Chloride & $0.35 \pm 0.05$ & $0.32 \pm 0.08$ & $0.31 \pm 0.10$ & $0.38 \pm 0.07$ & 0.89 \\
\hline Phosphorus & $0.18 \pm 0.02$ & $0.18 \pm 0.01$ & $0.19 \pm 0.01$ & $0.22 \pm 0.01$ & 0.32 \\
\hline Potassium & $1.70 \pm 0.13^{\mathrm{a}}$ & $2.91 \pm 0.27^{\mathrm{a}}$ & $2.80 \pm 0.33^{\mathrm{ab}}$ & $3.32 \pm 0.21^{\mathrm{a}}$ & 0.01 \\
\hline Sulphur & $0.18 \pm 0.01$ & $0.46 \pm 0.25$ & $0.30 \pm 0.12$ & $0.21 \pm 0.02$ & 0.54 \\
\hline Magnesium & $0.33 \pm 0.02$ & $0.56 \pm 0.19$ & $0.46 \pm 0.08$ & $0.36 \pm 0.02$ & 0.46 \\
\hline Sodium & $0.04 \pm 0.01^{\mathrm{a}}$ & $0.01 \pm 0.01^{\mathrm{b}}$ & $0.01 \pm 0.00^{\mathrm{b}}$ & $0.01 \pm 0.00^{\mathrm{b}}$ & 0.01 \\
\hline \multicolumn{6}{|l|}{ Micro minerals (g/kg DM) } \\
\hline Copper & $5.52 \pm 0.07$ & $4.13 \pm 0.24$ & $3.98 \pm 0.37$ & $4.53 \pm 0.87$ & 0.19 \\
\hline Zinc & $11.46 \pm 2.02$ & $8.61 \pm 0.46$ & $10.10 \pm 0.85$ & $10.93 \pm 0.69$ & 0.39 \\
\hline Iron & $65.54 \pm 6.53$ & $89.88 \pm 9.52$ & $78.47 \pm 5.11$ & $86.11 \pm 6.28$ & 0.15 \\
\hline Manganese & $32.71 \pm 0.62^{\mathrm{b}}$ & $51.55 \pm 2.85^{\mathrm{a}}$ & $46.50 \pm 3.11^{\mathrm{a}}$ & $55.92 \pm 2.35^{\mathrm{a}}$ & $<0.01$ \\
\hline
\end{tabular}

${ }^{a-b}$ Means within a row with different superscripts differ $(p<0.05)$.

Rumen degradable protein represents the fraction of intake CP that is degraded by rumen microbes to ammonia, amino acids or dipeptides in the rumen. This fraction consists of none protein nitrogen (NPN), amino acids and true protein that are degraded in rumen fluid $\left(\mathrm{A}, \mathrm{B}_{1}, \mathrm{~B}_{2}\right.$, and $\mathrm{B}_{3}$ protein fractions) with varying rates of rumen degradation and passage rates (Tylutki et al., 2008). Rumen microbes require RDP for microbial protein synthesis. A deficiency in RDP will result in reduced carbohydrate digestion, microbial yield and poor performance whereas excess RDP will result in loss of $\mathrm{N}$ as urea (Damiran et al., 2013; Nair et al., 2016). In the current study, rumen degradable protein as a percent of CP, did not differ $(p>0.05)$ among cultivars and averaged $68.0 \pm 0.5 \%$ crude protein. Similar to this, RDP (\% of CP) across cultivars indicated that microbial protein synthesis from either alfalfa or CMV protein was likely to vary little among cultivars. Although Oxley II was lower $(p<0.05)$, Oxley and Veldt were similar $(p>0.05)$ to AC Grazeland alfalfa for NDF, ADF and starch content. In contrast, Oxley II had greater $(p<0.05)$, and Oxley and Veldt were similar $(p>0.05)$ to AC Grazeland for $\mathrm{NE}_{\mathrm{g}}$ values. Whereas, all 3 CMV cultivars had similar levels of sodium $(0.01 \mathrm{~g} / \mathrm{kg})$, that were nevertheless, lower $(p<0.05)$ than that of AC Grazeland alfalfa $(0.04 \mathrm{~g} / \mathrm{kg})$. Gervais (2000) found that, in the full flowering stage, CMV had 15.4, 43.1, and $32.8 \% \mathrm{CP}, \mathrm{NDF}$, and $\mathrm{ADF}$, respectively, which are in agreement with current study forage values. 
All 3 CMV cultivars had similar $(p>0.05)$ levels of TDN $(63.6 \pm 0.6 \%)$ and manganese $(51.8 \pm 2.1 \mathrm{~g} / \mathrm{kg})$, nevertheless, were higher $(p<0.05)$ than AC Grazeland $(54.9 \pm 1.4 \% \mathrm{TDN}, 32.7 \pm 0.6 \mathrm{~g} / \mathrm{kg}$ manganese). Thus, cicer milkvetch varieties ranged from 14 to $19 \%$ (average 16\%) greater TDN content compared to AC Grazeland alfalfa. Relative feed value (RFV) is a forage quality term that is used to rank forages based on nutritive value (Jeranyama \& Garcia, 2004; Ward \& de Ondarza, 2008). An RFV of 100 is equivalent to full bloom AC Grazeland alfalfa having $41 \%$ ADF and 53\% NDF (Jeranyama \& Garcia, 2004), as RFV is calculated based on ADF and NDF content of alfalfa. In the current study, Oxley II CMV tended $(p=0.06)$ to have higher RFV (139), than AC Grazeland alfalfa (94), with the other CMV cultivars being intermediate (128). As RFV is based on alfalfa fiber content, Ward \& de Ondarza (2008) suggested that caution should be used when using this term for other forages, as RFV does not take into account the digestibility of the ADF and NDF fractions. Overall, in current study, forage quality (TDN and RFV) was similar among the CMV cultivars and greater than AC Grazeland alfalfa. In north eastern Saskatchewan, Loeppky et al. (1996), reported total in vitro digestible DM of CMV was $98 \%$ that of alfalfa in August, but $141 \%$ in September, when averaged across results of a $6 \mathrm{yr}$ study. Thus, the energy values observed in the current study are within the range reported by Loeppky et al. (1996). Further, a review of literature showed that in north eastern Saskatchewan (Loeppky et al., 1996), southern Alberta (Johnston et al., 1975), and Montana (Stroh et al., 1972), CMV retains its leaves longer and maintains forage quality (i.e.; TDN or in vitro digestibility) later in the season than does alfalfa (Medicago sativa $\mathrm{L}$.). Thus, the results of the current study were partly in agreement with these reported findings, where TDN content of CMV is greater than AC Grazeland alfalfa in late summer. The current study results also confirm that these new CMV cultivars, Oxley II and Veldt, have similar forage quality to the older cultivar, Oxley.

The NRC (2000) model predicts that a dry cow in early to mid-gestation requires 7 to $8 \%$ of CP in the diet for maintenance which increases to 11 to $13 \% \mathrm{CP}$ in young growing or lactating cows. Crude protein content of both CMV varieties and AC Grazeland alfalfa in current study was generally greater than 14\%, meeting the protein requirements of pregnant heifers and mature cows during their entire gestation period (NRC, 2000; Lardner et al., 2017). Using TDN as the energy source for beef cow, the rule of thumb is 55-60-65 (\%, DM) (Yurchak \& Okine, 2004). This rule states that for a mature beef cow to maintain her body condition score through the winter feeding period, the ration must have a TDN content of 55\% in mid pregnancy, $60 \%$ in late pregnancy and $65 \%$ after calving (Yurchak \& Okine, 2004). Therefore, current study results suggest that all three CMV cultivars had adequate energy required by gestating beef cows, mid pregnancy, as well as late pregnancy cows. This further confirms that alfalfa harvested at full maturity, will normally meet the nutritional requirements of a dry cow in mid pregnancy. Van Soest (1965) suggested that cell-wall constituents (NDF fraction) may limit intake when their concentration increases to more than 55 to $60 \%$ of the dry matter due to the effects of rumen fill. For all forage types (CMV and alfalfa) evaluated in the current study, NDF remained below 55\% for all cultivars. Although, considering that grazing animals typically ingest a higher quality diet than the clipping data showed (Damiran et al., 2013), it is likely that the concentration of NDF of these CMV cultivars may not have been great enough to limit intake. Finally, mineral requirements of beef cows can also vary with the stage and level of production (NRC, 2000). Forage mineral content can be affected due to changes in soil, season and stage of maturity (Kappel et al., 1985). All forages tested in the current study had sufficient amounts of $\mathrm{Ca}(>0.58 \% \mathrm{Ca})$ needed for pregnant heifers and mature cows during their entire pregnancy and post calving. Forage $\mathrm{P}$ content was ranged between 0.19 and $0.18 \%$ for CMV and AC Grazeland alfalfa, respectively. These values were well within the ranges suggested for dry gestating cows $(0.16 \% \mathrm{P})$ (NRC, 2000). But for lactating cows, which require $0.26 \% \mathrm{P}$ (NRC, 2000), and for finishing beef cattle which require $0.21 \% \mathrm{P}$, the forages fell short in meeting their P requirements. This therefore indicates that for cows in the late pregnancy stage, or for finishing beef cattle some form of mineral supplementation to address the short fall of forage P contents is needed.

\subsection{Forage Anti-Quality Profile}

The Se requirement of animals is about 0.1-0.5 ppm, while obvious deficiency symptoms (white muscle disease) occur when Se levels are less than $0.05 \mathrm{ppm}$. The Food and Drug Administration (FDA) permitted level of added Se in animal feeds ranges from $0.1 \mathrm{ppm}(0.1 \mathrm{mg} / \mathrm{kg})$ to $0.3 \mathrm{ppm}(0.3 \mathrm{mg} / \mathrm{kg})$ (the approved level was subsequently restored to $0.3 \mathrm{ppm}$ ). The results of current study suggested (data not shown) that Se concentrations were similar $(p>0.05)$ among CMV cultivars and less than $1 \mathrm{ppm}$. Likewise, no swainsonine nor nitrotoxins were detected (data not shown). Forage Se concentration $>5 \mathrm{mg} / \mathrm{kg}$ are presumed to be toxic to grazing ruminants (NRC, 2000). In agreement with the current study, a review of literature showed that unlike some native milkvetches (Damiran, 2005), new CMV cultivars do not accumulate greater selenium levels (Johnston et al., 1971; Acharya et al., 2006). 


\subsection{Foraging Behavior and Relative Preference Index}

Forage intake behavior and relative preference index data are presented in Table 2. Animals learn based on the consequences of their actions - positive consequences increase the likelihood of the behavior, whereas aversive consequences decrease the likelihood of the behavior (Provenza \& Launchbaugh, 1999). In current study, forage types did not differ statistically $(p>0.05)$ in cow feeding duration $(2.57 \pm 0.32 \mathrm{~min} / \mathrm{h})$, feeding head-down time $(1.20 \pm 0.21 \mathrm{~min} / \mathrm{h})$, and feeding frequency $(1.09 \pm 0.15 \mathrm{~min} / \mathrm{h})($ Table 2$)$. This may have been at least partly due to the short duration time ( $9 \mathrm{~d})$ of the study. Although forages did not differ $(p>0.05)$ for DMI rate by cow; the DMI rate of Oxley II, Veldt, and Oxley CMV was 4, 18\%, and $28 \%$ higher than that of AC Grazeland alfalfa, respectively in the late-summer study. Based on DMI rate, forages can be ranked as follows: Oxley and Oxley II (2.4) < AC Grazeland alfalfa and Veldt (2.6) (Table 2).

Table 2. Effect of cicer milkvetch cultivar types on beef cow feeding behavior and DMI rate

\begin{tabular}{lllllll}
\hline & Alfalfa & \multicolumn{2}{l}{ Cicer milkvetch } \\
\hline Traits $^{1}$ & AC Grazeland & Oxley & Oxley II & Veldt & SEM & $p$-value \\
\hline Feeding duration, min/h & 2.6 & 2.3 & 2.7 & 2.7 & 0.66 & 0.97 \\
Head-down time, min/h & 1.3 & 0.9 & 1.3 & 1.4 & 0.43 & 0.85 \\
Feeding frequency, visits/h/h & 1.1 & 1.0 & 1.2 & 1.1 & 0.30 & 0.98 \\
DMI rate, g DM/h & 93.7 & 119.6 & 97.1 & 110.4 & 25.13 & 0.88 \\
Rank $^{2}$ & 2.6 & 2.4 & 2.4 & 2.6 & 0.29 & 0.92 \\
\hline
\end{tabular}

Note. ${ }^{1}$ Feeding behavior data were recorded by the GrowSafe system (GrowSafe System Ltd, Airdrie, Alberta, Canada,) using 4 cows over a valid a 9-d period over 2 yr.

${ }^{2}$ Rank = Ranking is achieved by giving the ranking ' 1 ' to the biggest DMI rate value for within each day, ' 2 ' to the second biggest value so on. Forage with smallest DMI rate value will get the lowest ranking in the row.

Absolute preference index values for a particular plant species may indicate whether that plant is preferred or rejected, but the primary value of preference indices is to rank various plants with regard to their palatability under a specified set of circumstances (Krueger, 1972). Consistency of selection may be influenced by plant availability and distribution, i.e.; uniformly distributed plants might be more frequent in the diet than plants with irregular distribution. In current study, forage availability and distribution was similar (one node of each forage type each d). Preference indices have been used to take into account availability. A simple ratio of percentage of the plant in the diet to percentage in the herbage has been expanded to include frequency measurements (Krueger, 1972). However, in the current study forage DMI rate (either alfalfa or CMV cultivars) to AC Grazeland alfalfa (check cultivar) DMI rate was used as a relative preference index (Fig. 1). Based on the relative preference index, forages can be ranked as follows: AC Grazeland alfalfa (1.0) < Veldt (1.2) < Oxley (1.4) < Oxley II (1.7) (Fig. 1). To our knowledge, palatability research evaluating CMV with beef cattle is limiting (Twidwell \& Kephart, 1989; Acharya et al., 1996).

In studies conducted at the Lethbridge, Alberta, ewes and steers were offered CMV or alfalfa hay harvested at various stages of maturity (Acharya et al., 1996). The authors showed that ad libitum consumption of cicer milkvetch was generally similar to that of alfalfa which is in agreement with the current study. However, there is limited evidence that grazed CMV may be less palatable than other legumes (Twidwell \& Kephart, 1989) which contrasts with our results. In general, forage preference of cattle may vary seasonally depending on forage availability, quality and maturity. As indicated by results of the current study, cows selected numerically greater levels of CMV, and selected less alfalfa during the preference period. This may be attributed to several factors including: low level of anti-nutritive compounds; as Loeppky et al. (1996) indicated that CMV and alfalfa generally have a similar proportion of leaves, yet CMV retains its leaves much better than alfalfa throughout the growing season. Assessing nutritive value between legumes, AC Grazeland alfalfa averaged 55\% TDN and CMV varieties averaged $64 \% \mathrm{TDN}$, while protein values were similar for alfalfa and CMV.

\section{Conclusions and Implications}

The result of this study showed that Veldt, Oxley II, and Oxley cicer milkvetch had higher TDN compared to AC Grazeland alfalfa, while nutrient profiles were similar across the CMV cultivars. All the CMV cultivars had adequate energy required by gestating cows, during mid pregnancy, as well as late pregnancy cows. Forage preference results indicated that CMV palatability is superior when late-summer forage is fed compared to alfalfa harvested at a similar time. Additionally, unlike alfalfa, CMV does not cause bloat in the grazing animal. Study results did not find evidence of anti-quality compounds, as no swainsonine, nitrotoxins or high Se levels 
were detected in CMV cultivars. To this end, considering the low level on anti-nutritive compounds and high nutrient and palatability profile, CMV is an excellent legume for late-summer or fall season grazing in the Black soil zone of Saskatchewan.

\section{Acknowledgments}

This project was funded by the Saskatchewan Agriculture Development Fund (ADF\#20150173). The author's acknowledge Leah Pearce, Krystal Savenkoff and all the WBDC staff for their assistance with feeding management and data collection during this study. The authors also grateful to the Poisonous Plant Research Lab, USDA ARS (Logan, UT, USA) for anti-nutritive compound analysis.

\section{References}

Acharya, S. N., Kastelic, J. P., Beauchemin, K. A., \& Messenger, D. F. (2006). A review of research progress on cicer milkvetch (Astragalus cicer L.). Canadian Journal of Plant Science, 86, 49-62. https://doi.org/10.4141/P04-174

Acharya, S. N. (2001). AC Oxley II cicer milkvetch. Canadian Journal of Plant Science, 81, 749-751. Retrieved from http://www.nrcresearchpress.com/doi/pdf/10.4141/P00-170

Acharya, S. N. (2009). Veldt cicer milkvetch. Canadian Journal of Plant Science, 89, 511-513. https://doi.org/10.4141/CJPS08155

Acharya, S. N., Beauchemin, K. A., \& Wuerfel, R. L. (1996). Yield and quality of forage crops and cultivars. Alberta Agriculture Research Institute Project Final Report. Project \# AARI92-0168. 103 pp.

AOAC (Association of Official Analytical Chemists). (2000). Official methods of analysis (17th ed.). Arlington, VA. USA.

Canadian Council of Animal Care (CCAC). (2009). Guidelines on the care and use of farm animals in research, teaching, and testing. Retrieved from http://www.ccac.ca/Documents/Standards /Guidelines/Farm_Animals. pdf

Coulman, B., Goplen, B., Majak, W., McAllister, T., Cheng, K.-J., Berg, B., Hall, J., McCartney, D., \& Acharya, S. (2000). A review of the development of a bloat-reduced alfalfa cultivar. Canadian Journal of Plant Science, 80, 487-491. https://doi.org/10.4141/P99-087

Cheeke, P. (1998). Natural toxicants in feeds, forages, and poisonous plants. Interstate Publishers, Inc. 479 p.

Damiran, D. (2005). Palatability of Mongolian rangeland plants. Circular of information No.3. Union, Oregon, USA: Oregon State University, Eastern Oregon Agricultural Research Station. Oregon, USA. Retrieved from https://ir.library.oregonstate.edu/concern/administrative_report_or_publications/wm117q40w

Damiran, D., DelCurto, T., Findholt, S., Johnson, B., \& Vavra. M. (2013). Comparison of bite-count and rumen evacuation techniques to estimate diet quantity and quality in grazing cattle. Rangeland Ecology \&. Management, 66, 106-109. http://dx.doi.org/10.2111/REM-D-12-00046.1

Damiran, D., Jonker, A., McKinnon, J. J., McAllister, T., Abeysekara, S., Zhang, X., Yari, M., \& Yu, P. (2013). Evaluation of the feed value for ruminants of blends of corn and wheat distillers dried grains with solubles. Journal of Agricultural and Food Chemistry, 61, 4387-4395. Retrieved from https://pubs.acs.org/doi/pdf/10.1021/jf400595

Damiran, D., Penner, G. B., Larson, K., \& Lardner, H. A. (2018). Use of residual feed intake as a selection criterion on the performance and economics for replacement beef heifers. Professional Animal Scientist, 34, 156-166. https://doi.org/10.15232/pas.2017-01635.

Durunna, O. N., Mujibi, F. D., Goonewardene, L., Okine, E. K., Wang, Z., \& Moore, S. S. (2011). Feed efficiency differences and re-ranking in beef steers fed grower and finisher diets. Journal of Animal Science, 89, 158-167. https://doi.org/10.4141/A02-065.

Gervais, P. (2000). L'astragale pois chiche, la coronille bigarrée et le sainfoin (cicer milkvetch, crown vetch and sainfoin). Université Laval, Québec, 190.

Hall, M. B. (2009). Determination of starch, including maltooligosaccharides, in animal feeds: comparison of methods and a method recommended for AOAC collaborative study. Journal of AOAC International, 92, 42-49.

Jefferson P. G., Acharya S. N., \& Coulman, B. E. (2015). New cicer milkvetch varieties for fall pasture. ADOPT project final report. ADF 20110360. 
Jeranyama, P., \& Garcia, A. D. (2004). Understanding relative feed value (RFV) and relative forage quality (RFQ). Retrieved from https://openprairie.sdstate.edu/cgi/viewcontent.cgi?article=1351\&context=extension_extra.

Johnston, A., Smoliak, S., Hironaka, R., \& Hanna M. R. (1971). Oxley cicer milkvetch. Canadian Journal of Plant Science, 51, 428-429. https://doi.org/10.4141/cjps71-083.

Johnston, A., Smoliak, S., Hironaka, R., \& Hanna, M. R. (1975). Cicer milkvetch for Western Canada. Agriculture Canada, Research Branch, Ottawa, ON. Publication 1536.

Kappel, L. C., Morgan, E. B., Kilgore, L., Ingraham, R. H., \& Babcock, D. K. (1985). Seasonal changes of mineral content of southern forages. Journal of Dairy Science, 68, 1822-1827. https://doi.org/10.3168/jds.S0022-0302(85)81033-X.

Krishnamoorthy, U., Muscato, T. V., Sniffen, C. J., \& Van Soest, P. J. (1982). Nitrogen fractions in selected feedstuffs. Journal of Dairy Science 65, 217-225. https://doi.org/10.3168/jds.S0022-0302(82)82180-2.

Krishnamoorthy, U., Sniffen, C. J., Stern, M. D., \& Van Soest, P. J. (1983). Evaluation of a mathematical model of rumen digestion and an in vitro simulation of rumen proteolysis to eliminate the rumen-undegraded nitrogen content of feedstuffs. British Journal of Nutrition 50, 555-568. https://doi.org/10.1079/BJN19830127.

Krueger, W. C. (1972). Evaluating animal forage preference. Journal of Range Management, 25, 471-475. https://doi.org/10.2307/3897012.

Lardner, H. A., Pearce, L., \& Damiran, D. (2017). Evaluation of low heat unit corn hybrids compared to barley for forage yield and quality on the Canadian Prairies. Sustainable Agriculture Research 6, 90-102. https://doi.org/10.5539/sar.v6n1p90.

Linn, J. (2003). Energy in the 2001 dairy NRC: understanding the system. Retrieved from http://www.foragelab.com/Media/NRC2001.pdf.

Loeppky, H. A., Bittman, S., Hiltz, M. R., \& Frick B. (1996). Seasonal changes in yield and nutritional quality of cicer milkvetch and alfalfa in northeastern Saskatchewan. Canadian Journal of Plant Science, 76, 441-446. https://doi.org/10.4141/cjps96-078.

Nair, J., Penner, G., Christensen, D., Yu, P., Beattie, A., McAllister, T., Damiran, D., Preston, N., Fuhr, L., \& McKinnon. J. J. (2016). A Nutritional evaluation of common barley varieties grown for silage by beef and dairy producers in Western Canada. Canadian Journal of Animal Science, 96, 598-608. https://doi.org/10.1139/cjas-2017-0060.

NRC. (2000). Nutrient requirements of beef cattle. Update 2000. 7th ed. Washington D.C.: National Academy Press.

NRC. (2001). Nutrient requirements of dairy cattle. 7th rev. ed. National Academy Press, Washington, DC.

Provenza, F. D. (1995). Postingestive feedback as an elementary determinant of food preference and intake in ruminants. Journal of Range Management, 48, 2-17. https://doi.org/10.2307/4002498.

Provenza, F. D., \& Launchbaugh, K. L. (1999). Foraging on the edge of chaos. In: K. L. Launchbaugh, K. D. Sanders, J. C. Mosley (Eds.), Grazing behavior of livestock and wildlife. Idaho Forest, Wildlife \& Range. Exp. Sta. Bull. \#70, Univ. of Idaho, Moscow, ID., 1-12.

SAS Institute. (2003). SAS/STAT User's Guide, Version 9.2. Cary, NC, USA: SAS Institute, Inc. p. 707.

Saskatchewan Soil Survey. (1992). The soils of Prairie Rose rural municipality No. 309, Saskatchewan. Saskatchewan Institute of Pedology. University of Saskatchewan., Saskatoon, Canada.

Smoliak, S., \& Johnston, A. (1976). Variability in forage and seed production and seedling growth in Astragalus cicer. Canadian Journal of Plant Science, 56, 487-491. https://doi.org/10.4141/cjps76-080

Smoliak, S., Johnston, A., \& Hanna, M. R. (1972). Germination and seedling growth of alfalfa, sainfoin, and cicer milkvetch. Canadian Journal of Plant Science, 52, 757-762. https://doi.org/10.4141/cjps72-123

Stroh, J. R., Carleton, A. E., \& Seamands, W. J. (1972). Management of 'Lutana' cicer milkvetch for hay, pasture, seed and conservation uses. Montana Agric. Exp. Stn. Bull. 666. 16.

Townsend, C. E., Kenno, H., \& Brick. M. A. (1990). Compatibility of cicer milkvetch in mixtures with cool season grasses. Agronomy Journal, 82, 262-266. https://doi.org/10.2134/agronj1990.00021962008200020017x 
Twidwell, E. K. \& Kephart, K. D. (1989). Forage potential of cicer milkvetch. SD State Univ. Cooperative Extension Service, Publication F \& F 1.4 - 5.2, 8057, 2 pp.

Tylutki, T. P., Fox, D. G., Durbal, V. M., Tedeschi, L. O., Russell, J. B., Van Amburgh, M. E., Overton, T. R., Chase, L. E., \& Pell, A. N. (2008). Cornell net carbohydrate and protein system: a model for precision feeding of dairy cattle. Animal Feed Science and Technology, 143, 174-202. https://doi.org/10.1016/j.anifeedsci.2007.05.010.

Undersander, D., \& Moore, J. (2002). Relative forage quality. Focus on forage. Retrieved January 15, 2016 from http://www.foragelab.com/Media/Relative_Forage_Quality.pdf.

Van Soest, P. J., Robertson, J. B., \& Lewis, B. A. (1991). Symposium: Carbohydrate methodology, metabolism, and nutritional implications in dairy cattle. Journal of Dairy Science, 74, 3583-3597. https://doi.org/10.3168/jds.S0022-0302(91)78551-2.

Van Soest, P. J. (1965). Symposium on factors influencing the voluntary intake of herbage by ruminants: Voluntary intake in relation to chemical composition and digestibility. Journal of Animal Science, 23, 834-843. https://doi.org/10.2527/jas1965.243834x.

Ward, R., \& de Onderza, M. B. (2008). Relative feed value (RFV) vs. relative forage quality (RFQ). Retrieved from http://www.foragelab.com/Media/RFV_vs_RFQ-CVAS\%20Perspective.pdf

Weiss, W. P., Conrad, H. R., \& Pierre, St. N. R. (1992). A theoretically-based model for predicting total digestible nutrient values of forages and concentrates. Animal Feed Science and Technology, 39, 95-110. https://doi.org/10.1016/0377-8401(92)90034-4

Yurchuk, T., \& Okine, E. (2004). Agri-facts: Beef ration rules of thumb. Agdex 420/52-4. Retrieved from http://www1.agric.gov.ab.ca/\$department/deptdocs.nsf/all/agdex9146/\$file/420_52-4.pdf?

\section{Copyrights}

Copyright for this article is retained by the author(s), with first publication rights granted to the journal.

This is an open-access article distributed under the terms and conditions of the Creative Commons Attribution license (http://creativecommons.org/licenses/by/3.0/). 